\title{
Shi Tiesheng
}

\section{Tłumaczenie i opracowanie:}

\author{
Marta Binkowska, Joanna Krenz, Paulina Stangreciak \\ Uniwersytet im. Adama Mickiewicza, Poznań
}

\section{Eseje}

\section{Wprowadzenie}

Shi Tiesheng, którego trzy utwory prezentujemy w niniejszym numerze, jest postacią szczególną w literaturze chińskiej, jak również w dialogu interkulturowym między Chinami a Polską. Urodzony w 1951 r. w Pekinie powieściopisarz, eseista i poeta należał do pokolenia, którego młodość przypadła na czasy „rewolucji kulturalnej” (1966-76), ostatni okres dyktatury Mao Zedonga. W 1969 r., podobnie jak wielu jego rówieśników należących do grona tak zwanych „młodych intelektualistów”, został zesłany na wieś, by uczyć się od chłopów. W 1972 r. wrócił do Pekinu z powodu choroby, która okazała się nieuleczalna i wkrótce doprowadziła do trwałego paraliżu obu nóg. Od tego czasu Shi Tiesheng zmagał się z wieloma problemami zdrowotnymi, w tym między innymi niewydolnością nerek, która sprawiła, że musiał poddawać się regularnym dializom. Sam o sobie mawiał nieraz żartobliwie, że z zawodu jest pacjentem. Pisaniem zajął się pod koniec lat 70. W 1979 r. opublikowano jego pierwsze opowiadanie „Los miłości” (Aiqing de mingyun), zaś cztery lata później za „Moje odległe Qingpingwan” (Wode yaoyuan de Qingpingwan), nawiązujące do doświadczenia pobytu na wsi w czasach rewolucji, zdobył prestiżową Ogólnonarodową Nagrodę za Najlepsze Opowiadanie. Odtąd jego twórczość zyskiwała coraz większe zainteresowanie. W 1989 r. Shi Tiesheng poślubił Chen Ximi, z wykształcenia 
matematyczkę, która towarzyszyła mu przez resztę życia. Zmarł w ostatni dzień 2010 r. na wylew.

Do najważniejszych książek Shi Tieshenga należą zbiory opowiadań „Moje odległe Qingpingwan” (Wode yaoyuan de Qingpingwan, 1985) i „Niedziela” (Libairi, 1988), tomy esejów: „Zapiski ze szczelin choroby” (Bing xi sui bi, 2002) i „Wózek inwalidzki pyta o droge" (Fulun wen lu, 2010) oraz powieści „Notatki o zasadach” (Wuxu biji, 1996) i „Moje podróże w Ding Yi” (Wo Ding Yi zhi lü, 2006). Na podstawie jego opowiadania Chen Kaige wyreżyserował znany film „Życie na strunie" (Bian zou bian chang, 1991).

W 2017 r. Krystian Lupa wyreżyserował w Chinach pięciogodzinny spektakl z udziałem chińskich aktorów zatytułowany „Pijak Mofei” (Xujiuzhe Mofei), stanowiący reinterpretację noweli-scenariusza Shi Tieshenga „Zarys projektu sztuki teatralnej odgrywanej na scenie, której tło stanowi film" (Guanyu yi bu yi dianying zuo wutai Beijing de xiju zhi shexiang) w szerszym kontekście twórczości autobiograficznej Shi. Ważnym punktem odniesienia dla reżysera był między innymi zamieszczony w niniejszym numerze esej „Ja i Świątynia Ziemi” (Wo yu Ditan), uważany za jeden z najwybitniejszych esejów XX stulecia w literaturze chińskiej, figurujący we wszystkich podręcznikach do języka i literatury dla szkół ponadpodstawowych w Kraju Środka. Przedstawienie Lupy trafiło na deski wielu teatrów w Chinach, m.in. w Pekinie, Szanghaju i Tianjinie i zebrało znakomite recenzje.

Przez kilka miesięcy miałam przyjemność uczestniczyć w projekcie Lupy jako tłumaczka scenariusza oraz służąc pomocą tłumaczeniową podczas castingów, prób do sztuki oraz wywiadów i konferencji prasowych. Wtedy także poznałam Chen Ximi i mogłam wysłuchać jej bezcennych opowieści o ukochanym mężu. Dzięki jej uprzejmości publikujemy eseje „Ja i Świątynia Ziemi” oraz „Drzewko jaśminowe” (Hehuanshu) i „Moje marzenie” (Wode mengxiang), należące do najważniejszych autotematycznych tekstów Shi Tieshenga. Informacje biograficzne o autorze pochodzą z materiałów udostępnionych przez producentów sztuki, firmy Propel Performing Arts \& Media.

Joanna Krenz 


\section{Drzewko jedwabne}

Gdy miałem dziesięć lat, zająłem pierwsze miejsce w konkursie literackim. Matka była wtedy jeszcze młoda. Nagle zaczęła mi o sobie opowiadać, że jak była mała, to jej wypracowania były jeszcze lepsze, do tego stopnia, że nawet nauczyciel nie wierzył, że mogła sama coś takiego napisać.

- Nauczyciel przyszedł do nas do domu i spytał, czy ktoś ze starszych nie pomógł mi tego napisać. Chyba nie miałam wtedy jeszcze nawet dziesięciu lat - powiedziała.

Gdy to usłyszałem, poczułem się, jakby ktoś mi podciął skrzydła i specjalnie się zaśmiałem:

- Chyba? Co to znaczy, chyba jeszcze nie miałam dziesięciu lat?

Zaczęła wyjaśniać, a ja zacząłem udawać, że już jej nie słucham i odbijałem piłeczkę pingpongową o ścianę. Strasznie ją tym zdenerwowałem. Ale muszę przyznać, że była całkiem mądrą, a do tego najpiękniejszą na świecie kobietą. Właśnie uszyła sobie niebieską sukienkę w białe kwiaty.

Gdy miałem dwadzieścia lat, dostałem paraliżu w obu nogach. Pomyślałem, że poza malowaniem pisanek dla ludzi, powinienem zająć się jeszcze czymś innym. Parę razy zmieniałem zdanie, cóż to by mogło być, w końcu zdecydowałem, że chcę uczyć się pisać. Matka nie była już wtedy młoda i przez te moje problemy z nogami zaczęła siwieć. W szpitalu wyrazili się jasno, że mojej choroby obecnie nie da się wyleczyć. Mimo to matka dalej była kompletnie pochłonięta moim leczeniem. Szukała pomocy wszędzie, u lekarzy i znachorów, wydała na to mnóstwo pieniędzy. Zawsze gdy tylko znalazła jakiś cudowny lek, kazała mi go jeść, pić albo się nim obmywać, smarować czy pryskać, czasem moksować.

- To jest strata czasu! Przecież to w ogóle nic nie daje! - wykrzyknąłem. Całym sercem myślałem wtedy o pisaniu, jak gdyby właśnie to mogło mnie wyzwolić od mojej choroby.

- Spróbujmy jeszcze raz. Jeśli nie spróbujemy, to skąd miałbyś wiedzieć, że nic to nie da? - powiedziała. Za każdym razem trzymała się kurczowo nadziei, że teraz na pewno się uda. Niestety momentów zwątpienia było tyle samo, co momentów przypływu nadziei. Ostatnim razem tak mnie wysmarowała, że na moim biodrze pojawiły się odparzenia. Lekarz powiedział, że jest to naprawdę niebezpieczne w moim przypadku. Właściwie było to śmiertelne. Ale w ogóle się nie bałem. Myślałem sobie, że gdybym umarł, to nie byłoby źle, w sumie byłbym nawet szczęśliwy. Ale matka spanikowała i przez parę miesięcy doglądała mnie w dzień i w nocy, a gdy zmieniała opatrunek, mówiła: 
- Jak to się mogło stać? Zawsze przecież byłam ostrożna!

Na szczęście rany się zagoiły, inaczej chyba by zwariowała.

Później zauważyła, że piszę.

- No to pisz tam sobie - powiedziała. Zrozumiałem, że końcu straciła nadzieję, że wyleczy moje nogi.

- Jak byłam młoda, to też najbardziej lubiłam literaturę. A jak byłam mniej więcej w twoim wieku, to też chciałam być pisarzem - dodała. - Jak byłeś mały, to chyba zająłeś pierwsze miejsce w konkursie literackim, prawda? - przypomniała mi. Kompletnie zapomnieliśmy o moich chorych nogach. Chodziła wszędzie pożyczać dla mnie książki, nawet w deszczu czy śniegu pchała mój wózek do kina, zupełnie jak wtedy, gdy szukała dla mnie lekarza i miała jeszcze nadzieję.

Gdy miałem trzydzieści lat, wydałem moją pierwszą powieść. Matki nie było już wtedy na świecie. Po jakimś czasie moja inna powieść zdobyła nagrodę. Matka nie żyła już wówczas od dobrych siedmiu lat.

Po zdobyciu przeze mnie nagrody pod moimi drzwiami sterczało mnóstwo dziennikarzy chcących przeprowadzić ze mną wywiad. Wszyscy mieli dobre intencje, ale twierdzili, że trudno się ze mną rozmawia. Przygotowałem tylko jedną mowę i powtarzanie jej w kółko trochę mnie denerwowało. Ruszyłem na wózku, aby się ukryć, usiadłem pośród spokojnych drzew w małym parku i pomyślałem: „Boże, czemu tak wcześnie wezwałeś do siebie moją matkę?" Zdumiony, usłyszałem odpowiedź: „To było dla niej za trudne. Bóg widział, że tego już nie wytrzyma, więc wezwał ją do siebie." Zrobiło mi się lżej na sercu, otworzyłem oczy i zobaczyłem, jak wiatr hula pośród drzew.

Opuściłem park i błąkałem się bez celu po ulicach, nie chciałem wracać do domu.

Po śmierci matki przeprowadziliśmy się $\mathrm{w}$ inne miejsce. Rzadko wracałem tam, gdzie mieszkała matka. Mały dziedziniec, na który wychodziły drzwi jej domku, znajdował się w samym środku dużego placu. Czasami przyjeżdżałem tam na wózku posiedzieć sobie trochę, ale nigdy nie chciałem udać się na ten mały dziedziniec. Usprawiedliwiałem się tym, że trudno mi tam samemu wjechać na wózku. Starsze panie z sąsiedztwa wciąż traktowały mnie jak swojego wnuka, szczególnie wtedy, gdy przypominały sobie, że nie mam już matki. Ale nigdy o tym nie mówiły głośno, tylko gadały o czymś innym, miały mi za złe, że tak rzadko je odwiedzam. Siedziałem na środku placu, piłem herbatę $\mathrm{z}$ domu po lewej i jadłem melona $\mathrm{z}$ domu po prawej. Pewnego razu w końcu poruszyły temat mojej matki:

- Idź na ten mały dziedziniec i zobacz, jak pięknie w tym roku rozkwitło to jedwabne drzewko, które zasadziła twoja matka! 
Serce mi zadrżało, znów użyłem wymówki, że trudno mi tam samemu wjechać na wózku. Nikt już nic więcej na to nie powiedział, zaczęły gadać o czymś innym i dowiedziałem się, że w mieszkaniu, które wcześniej zajmowaliśmy, ulokowały się dwie małe osóbki. Dziewczyna właśnie urodziła syna, który ani nie płacze, ani nie krzyczy, tylko gapi się na cień rzucany przez drzewo na okno.

Nie spodziewałem się, że to drzewo jeszcze tu rośnie. Tego roku, gdy matka poszła do Urzędu Pracy szukać dla mnie jakiegoś zajęcia, wracając, wykopała z ubocza drogi ledwie odrosłą od ziemi „mimozę”. Przekonana, że jest to mimoza, zasadziła ją w doniczce. Ostatecznie okazało się, że to drzewko jedwabne. Matka od zawsze lubiła takie rzeczy, ale wtedy myślami była zupełnie gdzie indziej. Rok później drzewo w ogóle nie wypuściło pączków. Matka tylko westchnęła, ale wciąż nie miała serca wyrzucić tej roślinki i pozwoliła jej dalej rosnąć w glinianej doniczce. Znów minął rok, a drzewo wypuściło liście i nawet zakwitło. Matka długo się z tego cieszyła, pomyślała, że to dobry znak i często chodziła doglądać drzewka, nie chciała znów być nieostrożna. W kolejnym roku wyjęła drzewko $\mathrm{z}$ doniczki i posadziła je w ziemi pod oknem. Czasami mówiła, że nie wie, ile lat potrwa, aż zakwitnie. A w następnym roku się przeprowadziliśmy. $\mathrm{Z}$ rozpaczy zapomnieliśmy o tym małym drzewku.

Pomyślałem, że lepiej iść je zobaczyć niż pałętać się tak bez celu po ulicach. Chciałem też jeszcze raz popatrzeć sobie na mieszkanie, w którym żyła matka. Cały czas pamiętałem, że jest tam to dopiero co wydane na świat dziecko, które ani nie płacze, ani nie krzyczy, tylko gapi się na cień drzewa. Czy to cień tego drzewka jedwabnego? $\mathrm{Na}$ tym małym dziedzińcu nie było innych drzew.

Starsze panie z sąsiedztwa przywitały mnie serdecznie jak zawsze, jedne dolewały herbaty, a inne podpalały papierosy, wszystko podane pod nos. Żadna nie wiedziała o tym, że zdobyłem nagrodę, a może i wiedziały, tylko nie uważały, że to coś ważnego. Wciąż pytały o moje nogi i czy mam stałą pracę. Wtedy już naprawdę było niemożliwe, żeby dostać się na wózku na mały dziedziniec. Małe kuchnie dobudowane przed drzwiami wszystkich domostw były bardzo szerokie, przejście zrobiło się tak wąskie, że nawet ktoś, kto pchałby tylko rower, musiałby ciągle nim manewrować. Spytałem o jedwabne drzewko. Powiedziały, że rok w rok kwitnie, a urosło na wysokość domu. Więcej już go nie widziałem. Gdybym poprosił, żeby mnie ktoś zaniósł tam na plecach, to w sumie nie byłoby to niemożliwe. Bardzo żałuję, że przed dwoma laty sam nie pojechałem na wózku go obejrzeć.

Jechałem powoli ulicą, nie spieszyłem się do domu. Człowiek potrzebuje czasem chwili samotności. Smutek też może stać się radością. 
Pewnego dnia tamto dziecko urośnie, być może pomyśli o swoim dzieciństwie, przypomni sobie kołyszący się cień drzewa, przypomni sobie o swojej mamie, może pobiegnie zobaczyć to drzewo. Ale nie będzie wiedziało, kto je zasadził i jak.

Listopad, 1984

ttum. Paulina Stangreciak

\section{Moje marzenie}

Chyba jest tak, że ludzie bardziej lubią to, czego im brakuje. Mimo że nie mogę w ogóle ruszać nogami, to i tak jestem fanem sportu. Lubię oglądać nie tylko turnieje piłki nożnej, koszykówki i innych dyscyplin piłkarskich, lecz również lekkoatletykę, pływanie, boks, łyżwiarstwo, narciarstwo, kolarstwo i wyścigi samochodowe. Podsumowując, jestem wszechstronnym maniakiem sportu. Oczywiście oglądam to wszystko w telewizji, bo stadiony sportowe przed wejściem mają wysokie schody, na które nie byłbym w stanie wejść. Jeśli danego dnia w telewizji zapowiada się wspaniałe widowisko sportowe, to ja od rana, gdy tylko się obudzę, czuję się jak podczas jakiegoś święta. Przez cały dzień, cokolwiek robię, nie przestaję myśleć o tym wydarzeniu, a kolejne minuty i sekundy upływają mi w radosnym oczekiwaniu. Czasami obawiam się, że wiele ważnych zawodów skoncentruje się w ciągu jednego bądź kilku dni (jak miało to miejsce na przykład w przypadku dopiero co zakończonej olimpiady), przez co przekładam inne istotne sprawy na później.

Prawdę powiedziawszy, rzeczą numer dwa, którą uwielbiam, jest piłka nożna, rzeczą numer trzy jest literatura, a rzeczą numer jeden jest lekkoatletyka. Umiem powiedzieć, jakie w każdej dyscyplinie lekkoatletycznej są rekordy świata, kto je ustanowił, czy dany rekord utrzymał się długo, czy krótko. Na przykład rekord skoku w dal wśród mężczyzn ustanowiony przez Boba Beamona przez 20 lat nie mógł zostać pobity. Inna sprawa, że nie było to do końca sprawiedliwe. Beamon skoczył 8 metrów 90 centymetrów na wyżynnym terenie w Meksyku, a Carl Lewis skoczył 8 metrów 72 centymetry na nizinie, co w rzeczywistości jest nawet lepszym wynikiem, a jednak nie może zostać zaliczone jako rekord świata. Te wyniki zapamiętuję przy okazji. Urok lekkoatletyki nie leży w rekordach (ludzie i tak nie mają szans stać się bogami), lecz w tym, że w biegach czy skokach zostaje w pełni 
wyrażona ludzka siła, determinacja i gracja. Dlatego lekkoatletyka jest piękniejsza niż jakikolwiek taniec. W porównaniu z nią taniec wydaje się sztuczny, na siłę poddany mistyfikacji. Być może po prostu widziałem za mało tańca. Kiedy patrzysz na Lewisa albo na biegnącego Eda Mosesa, możesz odnieść wrażenie, że biegną od zarania dziejów człowieka, biegną nieustannie aż do jego przyszłości, a mięśnie całego ciała są niczym przetaczająca się nawałnica - to właśnie jest najnaturalniejszym tańcem i pieśnią wolności.

Człowiekiem, którego najbardziej lubię, a jednocześnie mu zazdroszczę, jest właśnie Lewis. Ma 1,88 m wzrostu, szerokie ramiona, długie nogi, przypomina czarnowłosego geparda, przebiega $100 \mathrm{~m}$ $\mathrm{z}$ łatwością w ciągu dziesięciu sekund, a jak skacze, to na ponad 8 metrów; ponadto na najważniejszych zawodach jego ruch jest tak regularny, zwinny, rytmiczny, absolutnie nie przypomina występów gwiazd pop, po których ludzie wątpią, co to w ogóle było. Możecie mnie i wyśmiać, ale ja często w sekrecie modlę się do nieba, powtarzając, że gdyby naprawdę było życie po śmierci, nie chciałbym nic innego, niż tylko mieć ciało tak dobre jak Lewis. Wyobrażam sobie, że ludzie po śmierci powinni być ogólnie wyżsi niż teraz, więc będę mieć na pewno przynajmniej ponad metr dziewięćdziesiąt; po drugiej stronie również sto metrów biega się szybciej niż tutaj, dlatego nie mógłbym poprzestać na marnych dziewięciu i dziewięćdziesięciu kilku setnych sekundy. Ludzie piszący powieści $\mathrm{w}$ większości są ofiarami marzycielstwa. Na szczęście to marzycielstwo w ogóle mnie nie martwi. I właśnie dlatego, że dość mam zmartwień w mojej rzeczywistości, rzeczywistości Shi Tieshenga, wymyśliłem ten sposób, aby sobie ulżyć i mieć czego pragnąć. Moje umiłowanie i adoracja Lewisa stopniowo wzrastała z każdym dniem. Wierzyłem, że jest on najszczęśliwszym człowiekiem na świecie. Jeżeli istniałby jakiś sposób, żebym mógł się w niego zamienić, z pewnością zapłaciłbym za to każdą cenę. Jeżeli po śmierci mógłbym mieć takie zdrowe i piękne ciało, to opłaca się przez całe życie znosić tortury kalectwa.

Na Igrzyskach Olimpijskich, w to południe, kiedy Johnson pokonał Lewisa, byłem niezmiernie smutny, czułem ciężar na sercu cały czas aż do wieczora, a w nocy również nie mogłem spać. Przed oczami pojawiała mi się południowa scena: wszyscy kibicują Johnsonowi, wszystkie flagi i kwiaty powiewają w jego stronę, fala dziennikarzy zalewa go podczas wychodzenia ze stadionu, a Lewis zostaje $\mathrm{z}$ boku. Jego pusty, zagubiony wzrok przypominał mi wzrok nieszczęśliwego dziecka, budził we mnie współczucie. Kilka dni z rzędu chodziłem niepocieszony, cały czas myślałem o tym, jak ten moment musiał być bolesny dla Lewisa. Nie chciałem oglądać powtórki tego biegu, nie 
chciałem słuchać, jak inni komentują to wydarzenie, doszło do tego, że zazdrościłem Johnsonowi tak, jakbym sam był Lewisem, a w głowie szukałem argumentów, by dowieść sobie, że Lewis jest najwspanialszy. Naturalnie wszystko na próżno, w końcu zacząłem się czuć, jakbym to ja sam przegrał, i to jeszcze sromotniej niż Lewis. Czyż nie jest to dziwne? Czy z boku nie wygląda to trochę na chorobę psychiczną? Zacząłem się zastanawiać, dlaczego tak jest. Czy to dlatego, że piękny idol został pokonany? Gdyby to tylko o to chodziło, to mógłbym natychmiast postanowić, że mam nowego idola, w końcu Johnson swoją postawą w niczym nie ustępuje Lewisowi. A może to dlatego, że jestem zbyt skłonny do nostalgii, w głębi zbyt konserwatywny? Ale rozumiałem przecież, że to, że po dobrych przychodzą lepsi, to raczej powód do świętowania. Może to, że Lewis nie pobiegł dobrze, sprawiło, że żałuję? Ale 9,92 sekundy było jego najlepszym wynikiem. To ostatecznie dlaczego? W końcu dotarło do mnie: widziałem nieszczęście tak zwanego „najszczęśliwszego człowieka”, nieobecny wzrok Lewisa sprawił, że moja definicja „największego szczęścia” zachwiała się, po czym runęła. Bóg nie daje charytatywnie nikomu plakietki „najszczęśliwszy", ustanowił wieczny dystans między Sobą i pragnieniami wszystkich ludzi, wyznaczając sprawiedliwie limity dla każdego. Jeśli nie można, przekraczając swoje ograniczenia, w nieskończonej wędrówce zrozumieć szczęścia, to moja niezdolność biegania niczym się nie różni od niezdolności Lewisa do biegania jeszcze szybciej, tak samo jest źródłem smutku i bólu. Jeśli Lewis tego nie rozumiał, to jestem przekonany, że $\mathrm{w}$ to wcześniej opisywane południe był on na pewno najbardziej nieszczęśliwym człowiekiem na ziemi.

Na drugi dzień po finałach biegu na $100 \mathrm{~m}$ Lewis osiągnął w zawodach w skoku w dal wynik 8 metrów 72 centymetry, a więc wszystko było w porządku. Wygląda na to, że Lewis zrozumiał, po co płonął boski ogień na górze Olimp. To wszystko nie jest po to, aby pojedynczy człowiek pokonał innego człowieka, ale po to, aby mieć okazję przed obliczem bogów pokazać swoją nieugiętość. Predestynowane ograniczenia zawsze będą istnieć, ale ani na moment nie można przestać rzucać im wyzwania. Nie odważyłbym się powiedzieć, że Lewis właśnie taki jest, ale mam taką nadzieję; całym sercem kocham, a nawet wielbię takiego Lewisa.

W ten sposób musiałem ponownie zaprojektować moje marzenie. Przynajmniej nie chcę już przy tym wszystkim, co sobie uświadomiłem, po prostu zamienić swoje ciało na lepsze, dostać wzrost ponad $1,90 \mathrm{~m}$ i osiągać czasy 9,79 s czy nawet 9,69 s. Powód jest bardzo prosty - nie chcę w życiu pośmiertnym w pewne południe stać się najbardziej nieszczęśliwym człowiekiem na świecie. Nawet jeśli człowiek 
może osiągnąć czas 9,59 s, to wciąż implikuje to ograniczenia. Chciałbym mieć zarówno zdrowe i piękne ciało, jak i duszę rozumiejącą sens istnienia. Aczkolwiek o ile o to pierwsze mogę prosić Boga, to to drugie powinienem osiągnąć, polegając na sobie i swoim trudzie, samemu dochodząc do tego, jaki kształt powinienem nadać swoim marzeniom. Jeśli nie można mieć tych dwóch rzeczy naraz, którą byś wybrał? Takiego pytania nie wolno zadawać, ponieważ człowiek aby żyć, potrzebuje najpiękniejszego marzenia.

Później dowiedziałem się, że Johnson osiągnął swój wynik 9,79 s, ponieważ stosował doping. Co powinniśmy powiedzieć o tym? Przeczytałem w gazecie wiadomość, że ludzie z jego ojczystej Jamajki mówią: „Kiedykolwiek Johnson zechce do nas wrócić, będzie mile widziany, bez względu na to, że zrobił coś źle, wciąż jest synem Jamajki”. To zdanie głęboko mnie poruszyło. Czyż to nie jest tak, że powinniśmy mieć więcej współczucia i miłości wobec ludzi upośledzonych duchowo niż wobec ludzi upośledzonych fizycznie?

Rok 1988

ttum. Marta Binkowska

\section{Ja i Świątynia Ziemi}

W moich nowelach i opowiadaniach wielokrotnie pojawiają się wzmianki o pewnym opuszczonym zabytkowym parku. Park ów to właśnie park otaczający Świątynię Ziemi.

Przed laty, zanim rozwinęła się u nas turystyka, miejsce to, niemal zapomniane i całkowicie zaniedbane, świeciło pustkami i zarastało dziką roślinnością.

Świątynia Ziemi znajduje się bardzo blisko mojego domu. Albo raczej - to mój dom znajduje się niedaleko Świątyni Ziemi. Tak czy inaczej, jestem pewien, że swój tajemniczy związek z tym miejscem zawdzięczam przeznaczeniu. Swiątynia Ziemi stanęła tu ponad czterysta lat przed moim urodzeniem, przez pięćdziesiąt lat, od czasu, kiedy babcia, wtedy jeszcze jako młoda kobieta, przyjechała wraz z moim tatą do Pekinu i zamieszkała w pobliżu Świątyni Ziemi, moja rodzina przeprowadzała się kilka razy, ale zawsze w okolice Świątyni, co 
więcej, z każdą przeprowadzką coraz bliżej. Często myślę sobie, że to los tak sprawił, że to tak, jakby ta Świątynia stanęła tam właśnie dla mnie, jakby dla mnie przeczekała te cztery wieki dziejowej zawieruchy.

Czekała najpierw na moje narodziny, a potem na ten moment, kiedy w wieku, w którym człowiekowi najtrudniej usiedzieć w miejscu, nagle straciłem władzę w nogach. Przez z górą czterysta lat dach jej odarty został z wymyślnych zdobień, zbladł dumny cynober na ścianach i odrzwiach, posypały się wysokie mury, poodpadały kawałki jadeitu, którymi inkrustowane były kolumny, cyprysy otaczające ołtarz rozrosły się dziko, trawy i pnącza rozpleniły się wszędzie.

Trafiłem na najwłaściwszy moment. Kiedy $\mathrm{w}$ pewne popołudnie piętnaście lat temu po raz pierwszy przybyłem do świątynnego parku, wszystko było tam gotowe na przyjęcie przygnębionego, zagubionego młodzieńca na wózku. Słońce, tym samym od wieków niebiańskim szlakiem, wędrowało nad horyzontem, coraz większe, coraz czerwieńsze. W wypełniającym park zastygłym słonecznym świetle można było dostrzec czas i swój własny cień.

Odkąd owego popołudnia zupełnie przypadkiem odwiedziłem ten park, nigdy na dłużej go nie opuściłem.

Ani przez chwilę nie miałem wątpliwości co do przyczyn jego powstania. Wspomniałem o tym zresztą w jednej z nowel, pisząc: „Musiał się Bóg nieźle nagłowić, by w sercu zatłoczonego miasta wygospodarować takie spokojne i bezludne miejsce".

Przez pierwsze parę lat mojej niepełnosprawności nie mogłem znaleźć pracy, nie mogłem znaleźć sobie miejsca, właściwie to niczego nie mogłem znaleźć, więc przyjeżdżałem do parku, po to tylko, żeby $\mathrm{w}$ tamten świat uciec przed tym światem.

„Nie mając dokąd pójść, całe dnie spędzałem w tym parku. Dokładnie tak, jakbym wyrabiał tam swój etat, kiedy inni szli do pracy, ja regularnie stawiałem się na dziedzińcu Świątyni Ziemi. Nikt tam nie bywał. Jedynie rano i po południu, gdy przechodziły tamtędy na skróty grupki ludzi spieszących się do pracy lub do domu, park na moment ożywał, by po chwili znów zatonąć w głębokiej ciszy".

„Mury parku rzucały zbawienny cień, w którym można było się schronić przed piekącym słońcem. Wjeżdżałem wózkiem przez bramę, zatrzymywałem się w cieniu, opuszczałem oparcie wózka i na siedząco lub na leżąco czytałem albo rozmyślałem. Odłamywałem cyprysową gałązkę i opędzałem się nią od owadów, które podobnie jak ja nie miały pojęcia, co robią na tym świecie".

„Chmara pszczół jak obłoczek leciutkiej mgły zawisła w powietrzu. Mrówka w geście samozadowolenia położyła czułki po sobie, po czym, 
tchnięta jakąś nagłą myślą, odwróciła się i oddaliła się w pośpiechu. Biedronka, znudzona wędrówką, przystanęła na moment, na odpoczynek i modlitwę, ale zaraz potem rozwinęła skrzydełka, zatrzepotała parę razy i wzbiła się w niebo. Na pniu drzewa pozostał pusty pancerzyk cykady, jak opuszczony dom. Spływające po źdźble trawy kropelki rosy połączyły się w jedną kroplę, która swoim ciężarem ugięła źdźbło i opadłszy na ziemię, rozbłysła tysiącem złotych promieni”.

„W parku czuć było nieustanne poruszenie, zewsząd dochodziły szumy, szelesty, chrobotania gęstniejących traw i drzew, które walczyły między sobą o każdy kawałek przestrzeni".

To fragmenty tej samej noweli. Wszystko to są rzeczywiste opisy, park był zaniedbany, ale bynajmniej nie chylił się ku upadkowi.

Oprócz kilku pawilonów, do środka których nie mogłem się dostać i ołtarza, na który nie zdołałbym się wspiąć, więc tylko spoglądałem na niego to z tej, to z innej strony, zjeździłem wszystkie zakątki parku, dotarłem pod każde drzewo, na każdym metrze kwadratowym trawnika odcisnąłem ślady kół mojego wózka. Bywałem tam niezależnie od pory roku, pory dnia, pogody. Czasami przyjeżdżałem tylko na chwilkę i wracałem do domu, innym razem zostawałem do późnego wieczora, czekając, aż ziemia pokryje się srebrną księżycową poświatą. Nie potrafię już połączyć poszczególnych myśli, jakie rodziły się w mojej głowie, z konkretnymi zakątkami parku. Zdarzało mi się przez kilka godzin w najwyższym skupieniu dywagować o sprawach związanych ze śmiercią, kiedy indziej z nie mniejszym zaangażowaniem próbowałem rozszyfrować, dlaczego się urodziłem. Myślałem tak przez ładnych parę lat, aż w końcu zrozumiałem: rodzimy się - i tyle, nie ma o czym dyskutować, to fakt dokonany, przed którym Bóg stawia każdego z nas; stawiając nas wszakże przed tym faktem, zaplanował zarazem, jak to wszystko się skończy, z tego wniosek, że nie ma sensu przyśpieszać nadejścia śmierci, bo ta uroczysta chwila prędzej czy później stanie się także naszym udziałem. Ta perspektywa wlała w moje serce otuchę, rzeczywistość dokoła już nie napawała mnie takim lękiem. To tak samo jak kiedy, powiedzmy, tygodniami zarywasz noce, każdą chwilę wykorzystując na przygotowanie się do egzaminu, i nagle wspomnisz, że przecież przed tobą są długie, zasłużone wakacje, od razu lżej, prawda? Czuje się radość i wdzięczność, że tak się to wszystko składa...

Pozostaje jeszcze pytanie, jak żyć. To jednak nie jest problem, który można by w jednej chwili rozstrzygnąć raz na zawsze. Historia naszego życia, długa czy krótka, to $\mathrm{w}$ istocie historia nieustannych zmagań $\mathrm{z}$ tym pytaniem, towarzyszy ono człowiekowi aż do śmierci, jak diabeł albo współmałżonek. Dlatego też od piętnastu lat ciągle odwiedzam ten park, zatrzymując się pod starymi drzewami, pośród dzikiej trawy 
albo przy gruzach podupadłych murów, siedzę tak sobie w milczeniu, zadumany, $\mathrm{z}$ dala od zgiełku świata porządkuję chaotyczne myśli, przyglądam się swojej własnej duszy.

W ciągu tych piętnastu lat park upiększali bezczelnie nic nierozumiejący nadgorliwi renowatorzy, na szczęście są rzeczy, których nikt nie jest w stanie zmienić. Na przykład promienie zachodzącego słońca przedzierające się przez kamienną bramę prowadzącą do ołtarza, moment, kiedy światło rozlewa się na ziemi, tworząc błyszczące kałuże we wszystkich nierównościach. Na przykład jaskółki zrywające się do lotu w chwili największego spokoju i rozpoczynające pieśń, od której niebo i ziemia napełniają się melancholią. Na przykład ślady dziecięcych stóp na śniegu, z których próbuje się wyczytać, do kogo należą, skąd prowadzą i dokąd biegną. Na przykład te wiekowe, czarne cyprysy - kiedy jest ci smutno, one trwają w niewzruszonym spokoju, kiedy przepełnia cię radość, stoją tak samo spokojnie, dzień i noc stoją, stały, gdy ciebie jeszcze nie było i będą stały, gdy ciebie już nie będzie. Na przykład burza, która nadciąga niespodziewanie i zawisa nad parkiem, całą naturę wprowadzając w stan napięcia i podniecenia, uwalniając z roślin i gleby ostry, świeży zapach, tak że człowiek wraca myślą do letnich dni. Na przykład nagłe uderzenie jesiennego wiatru. Albo jeszcze - szron o świcie, opadłe liście, które to wirują w powietrzu, to znów ścielą się kolorowym dywanem na ziemi, a wszędzie dokoła unosi się ledwo wyczuwalny, gorzkawy zapach. Zapach najtrudniej oddać słowami. Zapachu nie można opisać, można tylko poczuć, sam musisz odwiedzić to miejsce, powąchać, wtedy zrozumiesz, o czym mówię. Zapach nawet zapamiętać jest trudno. Dopiero gdy poczujesz go ponownie, wyzwala w tobie te same emocje, znów odsłania się przed tobą jego głębia. Dlatego właśnie tak często odwiedzam ten park.

\section{II}

Dopiero teraz zdałem sobie sprawę z tego, jak trudne musiały być dla mojej matki te moje samotne wycieczki do Świątyni Ziemi.

Moja matka nie należała do matek chorobliwie kochających, ale za grosz nierozumiejących swoich synów. Wiedziała, co czuję, wiedziała, że nie może mnie zatrzymywać, że jeśli będę całymi dniami przesiadywał w domu, skończy się to jeszcze gorzej, choć jednocześnie martwiła się potwornie, co też może mi przyjść do głowy podczas tych moich samotnych wycieczek do opuszczonego parku. Byłem paskudnym dzieckiem, często wybiegałem $\mathrm{z}$ domu jak wariat, zaś po powrocie z parku milczałem jakby wlazł we mnie jakiś demon. Mama wiedziała, że są sprawy, o które nie należy pytać, widziałem, jak nieraz 
biła się z myślami, jak już-już miała zadać pytanie, ale nie śmiała, bo sama nie miała pojęcia, co można by na takie pytanie odpowiedzieć. Spodziewała się, że nie byłbym zadowolony, gdyby chciała towarzyszyć mi w tych moich spacerach, dlatego też nigdy o tym nie wspominała. Wiedziała, że potrzeba mi trochę czasu dla siebie, że to jest proces, przez który muszę przejść sam. Nie wiedziała tylko, że proces ten potrwa tak długo i do czego ostatecznie doprowadzi. Za każdym razem, gdy sygnalizowałem zamiar wyjścia, bez słowa pomagała mi się zebrać, wsiąść na wózek, po czym patrzyła, jak opuszczam podwórko; co się $\mathrm{z}$ nią działo potem - nie raczyłem się zainteresować.

Pewnego razu tuż za bramą przypomniałem sobie o czymś i zawróciłem, zobaczyłem wtedy, że matka nadal stoi w tym samym miejscu, w dokładnie takiej samej pozycji, w jakiej stała, gdy wychodziłem, i wpatruje się w miejsce, w którym zniknąłem jej z oczu. W pierwszej chwili w ogóle nie zorientowała się, że wróciłem. Kiedy ponownie odprowadzała mnie do drzwi, powiedziała: „Jedź, dobrze ci zrobi taki spacer do Świątyni Ziemi, posiedzisz tam sobie, poczytasz". Wiele lat upłynęło, zanim zrozumiałem, że w tych słowach kryła się w rzeczywistości próba dodania otuchy samej sobie, że to była taka jej sekretna modlitwa, a zarazem wskazówka dla mnie, nieśmiałe błaganie i dyskretne upomnienie. Dopiero po jej niespodziewanej, przedwczesnej śmierci znalazłem czas, by się nad tym zastanowić. By sobie wyobrazić, jak przez te długie godziny, kiedy nie było mnie w domu, siedziała jak na szpilkach, splatając swój ból i strach w najprostszą matczyną litanię. Teraz dopiero odgaduję, ile się musiała nawalczyć sama ze sobą w te samotne dni nastające po bezsennych nocach, by w końcu $\mathrm{z}$ całą tą swoją mądrością i niezłomnością powiedzieć sobie: „Tak czy inaczej, nie mogę go zatrzymywać. Przyszłość, którą ma przed sobą, będzie należeć do niego samego. Jeśli coś ma mu się stać w tym parku, nie pozostaje mi nic innego, jak wziąć na siebie ciężar tego cierpienia".

Myślę, że w tamtym okresie, w tamtym bardzo długim okresie, matka musiała spodziewać się po mnie najgorszego, ale nigdy nie powiedziała mi: „Mógłbyś czasem pomyśleć trochę o mnie”. Szczerze mówiąc, w ogóle o niej wtedy nie myślałem. Jej syn był jeszcze wtedy za młody, jeszcze nie zdążył pomyśleć o matce, dostał po głowie od losu i wydawało mu się, że jest najnieszczęśliwszym człowiekiem na świecie, nie miał pojęcia, że cierpienie dziecka w sercu matki pomnaża się wielokrotnie. Jej syn, jej jedyny syn, w wieku dwudziestu lat został kaleką. Wiele by dała za to, żeby to jej nogi odmówiły posłuszeństwa, żeby mogła wziąć na siebie nieszczęście dziecka, ale w tym jednym nie mogła mnie zastąpić. Myślała sobie pewnie: niech tylko mój syn przeżyje, ja mogę umrzeć, to nic, ale jednocześnie przecież rozumiała 
doskonale, że samo życie to jeszcze nie wszystko, że syn potrzebuje drogi, którą będzie mógł podążyć do szczęścia, a kto jej zagwarantuje, że w końcu uda mu się odnaleźć tę drogę. Matkom takim jak moja jest na tej ziemi najtrudniej i najsmutniej.

Spytałem kiedyś jednego z moich kolegów po piórze, co go skłoniło, by zająć się pisaniem. Po chwili namysłu odpowiedział mi: „To dla mojej matki. Żeby mogła być ze mnie dumna". Zdziwiła mnie jego odpowiedź, długo milczałem. Próbowałem sobie przypomnieć impuls, który mnie popchnął do napisania pierwszej nowelki. Choć nie była to motywacja tak prosta i jednoznaczna, jednak przecież i we mnie było podobne pragnienie, co więcej, jeśli się nad tym dłużej zastanowić, miało na mój wybór artystycznej drogi całkiem niemały wpływ. Kolega zapytał: „Pewnie sądzisz, że to zbyt przyziemna motywacja?” Pokręciłem tylko głową, w głębi duszy mówiąc sobie: przyziemność niekoniecznie musi być przyziemna, obawiam się tylko, że to zbyt naiwne pragnienie. Kontynuował więc: „Naprawdę zależało mi wtedy, by stać się sławnym, żeby ludzie zazdrościli mojej matce takiego znanego syna". Myślę, że ten kolega jest dużo bardziej szczery niż ja i że ma więcej szczęścia, bo jego matka nadal żyje, i jeszcze, że dla jego matki los był łaskawszy niż dla mojej, bo nie ma syna kaleki, i że gdyby miała, wówczas to wszystko nie byłoby takie proste.

Kiedy ukazała się moja pierwsza nowela, a potem kiedy odbierałem pierwszą w życiu nagrodę literacką, tak bardzo chciałem, żeby moja matka mogła być wtedy ze mną. Nie mogłem usiedzieć w domu, całe dnie spędzałem samotnie w parku przy Świątyni Ziemi, pogrążony w smutku i melancholii, przemierzyłem cały park wzdłuż i wszerz, ale nadal nie mogłem pojąć: dlaczego matka nie mogła pożyć jeszcze te dwa lata? Dlaczego akurat wtedy, gdy jej syn już-już miał wstąpić na drogę, która mogła go poprowadzić do czegoś większego, matka tak nagle odeszła? Czyżby na tym świecie przewidziano dla niej tylko długie miesiące zamartwiania się o własne dziecko, a niedane jej było dzielić z nim jego radości? Przecież miała dopiero 49 lat! Był taki moment, gdy potwornie znienawidziłem Boga za to wszystko, co nam zrobił. W eseju „Albicja” napisałem o tym tak: „Siedziałem w parku, pośród milczących drzew, z zamkniętymi oczami zadawałem sobie ciągle to samo pytanie: dlaczego Bóg tak wcześnie wezwał moją matkę do siebie? Dużo czasu upłynęło, zanim, zrezygnowany i kompletnie zbity z tropu, usłyszałem w końcu w duszy taką odpowiedź: spotkało ją tyle nieszczęść, Bóg sam nie mógł już patrzeć na jej cierpienie, więc zawołał ją z powrotem do nieba. Ta myśl przyniosła mi ukojenie. Otworzyłem oczy, zobaczyłem, jak wiatr przemyka między gałęziami drzew". 
Park, o którym mowa, to oczywiście ten sam park otaczający Świątynię Ziemi.

To wtedy po raz pierwszy cała moja pogmatwana przeszłość ukazała mi się przed oczyma w pełnym świetle, dopiero wtedy uświadomiłem sobie wielkość mojej matki i ogrom jej cierpienia. Może jednak Bóg miał rację.

Snułem się tak po parku, najpierw przez cały mglisty poranek, i dalej, w pełnym słońcu południa, myśląc tylko o jednym: matki już nie ma. W cieniu starych cyprysów, na trawniku ścielącym się u stóp podupadłych murów, przez całe popołudnie wypełnione brzęczeniem owadów i jeszcze wieczorem, gdy kruki powracały do gniazd, w duszy powtarzałem jak mantrę tylko to jedno zdanie: ale matki już nie ma. Opuściłem oparcie wózka, położyłem się i tak w półśnie dotrwałem do zmierzchu, ponownie podniosłem oparcie i jak w transie siedziałem aż do momentu, gdy stary ołtarz utonął $\mathrm{w}$ nieprzeniknionych ciemnościach, a potem znów wyłonił się z nich, oświetlony słabym blaskiem księżyca. Dopiero wtedy zaczęło do mnie docierać, że matka już więcej tu po mnie nie przyjdzie.

Zdarzało się wcześniej wielokrotnie, że kiedy zbyt długo nie wracałem do domu, przychodziła mnie szukać. Szukała mnie, ale tak, bym się nie zorientował, upewniwszy się, że wszystko w porządku, że nadal siedzę w parku, wycofywała się niepostrzeżenie. Kilka razy widziałem jej oddalającą się sylwetkę. Widziałem też nieraz, jak rozglądała się za mną, miała słaby wzrok, unosząc okulary, wyglądała, jakby wypatrywała łódki na morzu. Zauważałem ją, zanim jeszcze ona zdążyła zauważyć mnie. Czekając, aż ona również mnie zobaczy, starałem się nie spoglądać w jej kierunku, dopiero po chwili podnosiłem głowę, by popatrzeć, jak powolutku opuszcza park. Nigdy się nie dowiem, ile razy nie udało jej się mnie znaleźć. Któregoś dnia siedziałem sobie w zagajniku, zarośla nie były wysokie, ale bardzo gęste, ukryty pośród nich, obserwowałem, jak bezowocnie mnie poszukuje. Chodziła sama po parku, przeszła tuż obok mnie, obeszła wszystkie miejsca, w których często bywałem, posuwając się szybkim, choć zarazem niepewnym krokiem. Nie mam pojęcia, jak długo mnie wtedy szukała, nie mam pojęcia, dlaczego jej nie zawołałem - nie była to w każdym razie dziecinna zabawa w chowanego, był w tym raczej upór i nieśmiałość młodego mężczyzny... Upór ten jednak przypisać należy wszakże jedynie mojej wstydliwości, nie było w nim śladu pychy czy arogancji. Tak bardzo chciałbym powiedzieć wszystkim chłopakom, że w relacji $\mathrm{z}$ matką taki upór do niczego nie prowadzi, a wstyd jest tym bardziej zbędny. Ja sam zrozumiałem to, kiedy dawno było już za późno. 
W wyznaniu syna, który pragnie, by matka mogła się nim poszczycić, jest tyle szczerości i autentyczności, że nawet to obmierzłe „chciałem być sławny" zabrzmiało jakoś mniej odpychająco. To skomplikowana sprawa, szkoda czasu na roztrząsanie tego. Kiedy emocje związane z nagrodą zaczęły opadać, przyszło mi do głowy, że jednak nie do końca miałem rację: czy ta droga, którą sobie wytyczyłem piórem na łamach prasy, to aby na pewno droga, którą wymarzyła sobie dla mnie matka? Przychodziłem więc dalej, miesiącami, latami do mojego parku, zastanawiając się, czego tak naprawdę chciałaby dla mnie ona...

Matka nie przekazała mi przed śmiercią żadnego przesłania, żadnej życiowej mądrości, nie zostawiła nauki, której miałbym przestrzegać, dopiero po śmierci ten jej trudny los, ta jej niezłomna wola i pokorna, nienarzucająca się miłość z biegiem czasu zaczęły jawić mi się coraz wyraźniej, odkrywając przede mną swą głębię.

Któregoś roku w październiku, gdy wiatr po raz kolejny podrywał do tańca opadłe liście, czytając książkę, usłyszałem rozmowę dwojga staruszków przechadzających się po parku: „Kto by się spodziewał, że ten park taki wielki...” Odłożyłem książkę, pomyślałem sobie: taki wielki park, ile się musiała po nim nachodzić moja strapiona matka... Po tylu latach pierwszy raz uświadomiłem sobie, że to nie tylko ja przemierzyłem każdy zakątek tego parku, że każdy kawałek ziemi poznaczony bruzdami po kołach mojego wózka nosi na sobie także ślady stóp mojej matki.

III

Gdyby próbować streścić w jednym dniu cały rok, poranek odpowiadałby bez wątpienia wiośnie, południe - latu, wieczór - jesieni, a noc - zimie. Jeśliby próbować przypisać czterem porom roku instrumenty muzyczne, wiośnie przypaść powinna w udziale trąbka, latu - bęben, jesieni - wiolonczela, zimie zaś - róg i flet. A gdyby pory roku skojarzyć z odgłosami w parku? Wiosna - to byłoby gruchanie gołębi przelatujących nad głównym ołtarzem, lato - nieprzerwane, monotonne pieśni cykad i szmer topól, których liście szeleszczącym chichotem kwitują ów śpiew owadzi, jesień - to byłyby dzwonki zawieszone na krokwiach zabytkowych świątynnych pawilonów, wreszcie zima - stukanie dzięcioła. Gdyby opisać pory roku za pomocą obiektów znajdujących się w parku, wiośnie odpowiadałyby to białe jak śnieg, to znów czarne jak heban parkowe ścieżki, i jeszcze te niekiedy błyszczące jak świetliki, innym razem przyprószone popiołem mroku, unoszące się w powietrzu kwiaty topoli, latu - rażące w oczy i parzące w tyłek kamienne ławeczki albo znajdujące się $\mathrm{w}$ cieniu omszałe, chłodne 
kamienne schody, pod schodami mnóstwo skórek po owocach, a na schodach sprasowane pupami płachty codziennych gazet, jesieni odpowiadałby mosiężny dzwon w południowo-zachodniej części parku, równie wiekowy jak sam park, cały pokryty zielonkawym nalotem i nieczytelnymi już inskrypcjami, zimie zaś - stadko wyliniałych wróbli na nagiej ziemi. A gdyby porom roku przyporządkować nastroje? Wiosna byłaby porą obłożnych chorób, żebyśmy w pełni mogli uświadomić sobie jej okrucieństwo i zachłanność, lato byłoby porą odkochiwania się zakochanych, żebyśmy poznali wartość miłości, jesień byłaby czasem, gdy kupuje się kwiat $\mathrm{w}$ doniczce, stawia się $\mathrm{w}$ domu, w którym się dawno nie bywało, otwiera się okno, by wpuścić do środka trochę światła i powolutku, ostrożnie porządkuje się nadgniwające przedmioty, wreszcie zima - czasem, gdy w towarzystwie kominka i książki składa się solenne obietnice i pisze listy, których się nigdy nie wyśle. Można też przypisać porom roku rodzaje sztuki, wówczas wiosnę skojarzyć należałoby z obrazem, lato - z powieścią, jesień - z piosenką albo wierszem, zimę - z rzeźbą. A sny? Jeśliby opisać pory roku za pomocą snów? Wiosna byłaby krzykiem dobiegającym $\mathrm{z}$ wierzchołka drzewa, lato byłoby deszczem zaklętym w tym krzyku, jesień byłaby ziemią skąpaną w deszczu, a zima - fajką leżącą samotnie na czystej jak łza ziemi.

Często czuję wdzięczność wobec losu, że dał mi ten park.

Boję się nawet myśleć, jak bardzo będę tęsknił za tym miejscem, jeśli zdarzy się, że nie będę mógł go odwiedzić przez dłuższy czas, $\mathrm{z}$ jakim rozrzewnieniem będę je wspominał i ile razy zobaczę je w snach, a gdy już nie będę miał siły wspominać, to i w snach przestanie mi się ukazywać.

IV

Niech pomyślę... ile znalazłoby się osób, które przez te piętnaście lat regularnie przychodziły do parku? Zdaje się, że zostałem tylko ja i para staruszków.

Piętnaście lat temu ci państwo byli małżeństwem w średnim wieku, mnie zaś bez wahania określić można było jako młodzieńca. Zjawiali się zawsze pod wieczór, nie dociekałem zbytnio, którą bramą wchodzili, zwykle spacerowali dookoła w kierunku przeciwnym do ruchu wskazówek zegara. Mężczyzna był wysoki, barczysty, długonogi, szedł, patrząc prosto przed siebie, $\mathrm{z}$ wyprężonym tułowiem, zdawało się, że od bioder aż po szyję w jego ciele nie drga ani jeden mięsień. Nawet żona, uwieszona u jego ramienia, nie była w stanie sprawić, by choć o milimetr pochylił się w jej stronę. 
Kobieta była niskiego wzrostu, nieszczególnie ładna, nie wiedzieć czemu byłem święcie przekonany, że musiała pochodzić z jakiegoś zubożałego arystokratycznego rodu. Trzymając się kurczowo mężowskiego ramienia, wyglądała jak bezbronne dziecko, rozglądała się na wszystkie strony, jakby w ciągłym strachu, mówiła do męża bardzo cichutko, a kiedy tylko orientowała się, że ktoś jest w pobliżu, natychmiast trwożliwie przerywała wypowiedź. Nieraz na ich widok przypominali mi się Jean Valjean i Kozeta, co wszakże było skojarzeniem zupełnie nieuzasadnionym, gdyż na pierwszy rzut oka widać było, że to dwoje starszych ludzi. Ich ubrania były schludne i starannie dobrane, niemniej jednak widać było, że w kwestiach mody małżonkowie zdecydowanie nie nadążają za duchem czasu. Tak samo jak ja, czy słońce, czy deszcz, wiernie stawiali się w parku, tyle że bardziej niż ja trzymali się określonej pory. Dla mnie każda godzina była równie dobra, by odwiedzić to miejsce, oni zaś przychodzili zawsze w momencie, gdy zaczynało się ściemniać. W wietrzne dni mieli na sobie beżowe wiatrówki, kiedy padało, zakładali czarne peleryny, latem ubierali się w białe koszule i czarne albo beżowe spodnie, a zimą w czarne, wełniane płaszcze, widocznie lubili tylko te trzy kolory. Okrążali park w kierunku przeciwnym do ruchu wskazówek zegara, po czym wychodzili.

Kiedy się mijaliśmy, słyszałem tylko odgłos kroków mężczyzny, kobieta zaś zdawała się przefruwać bezszelestnie, uczepiona jego silnego ramienia. Jestem pewien, że moja osoba musiała ich do pewnego stopnia intrygować, jednak nigdy ze sobą nie rozmawialiśmy, nigdy żadne $\mathrm{z}$ nas nie wykazało chęci nawiązania jakiejkolwiek relacji. W ciągu tych piętnastu lat zaobserwowali być może, że oto młodzieniec, którego widywali od tak dawna, wszedł już w wiek dojrzały, ja z kolei byłem świadkiem przemiany dwojga ludzi w średnim wieku w dwoje staruszków.

Bywał tam też pewien chłopak, który uwielbiał śpiewać. Przychodził co dzień do parku i śpiewał. Śpiewał tak przez parę lat, a potem nagle przestał się pojawiać. Był w podobnym wieku co ja, zjawiał się zazwyczaj wczesnym rankiem, śpiewał czasem pół godziny, czasem całe przedpołudnie, przypuszczam, że poza tym śpiewaniem miał jeszcze pracę, do której musiał chodzić. Często spotykaliśmy się na ścieżce po wschodniej stronie ołtarza, wiedziałem, że idzie pośpiewać w południowo-wschodnim zakątku parku, on zaś zapewne domyślał się, że ja wybieram się do zagajnika $\mathrm{w}$ północno-wschodniej części w jakimś mnie tylko wiadomym celu. Kiedy docierałem do mojego miejsca, wyciągałem papierosa, jeszcze dobrze nie zdążyłem poczuć jego smaku, gdy do moich uszu dochodził głos chłopaka, pieczołowicie ćwiczony i szlifowany zawzięcie. Miał stały repertuar, składający się z kilku 
utworów. W czasie trwania Rewolucji Kulturalnej śpiewał: „Wiatr białe obłoki po błękicie goni, pod obłokami jak wicher pędzi stado koni..." Nigdy nie mogłem zapamiętać tytułu tej piosenki. Po Rewolucji natomiast przestawił się na najsłynniejsze arie $\mathrm{z}$ „Handlarza i panny”. „Materiał, kupujcie materiał, materiał, kupujcie materiał!” Pamiętam, że te początkowe nuty brzmiały w jego wykonaniu szczególnie mocno, głos jego niósł się w czystym, porannym powietrzu, handlarz biegał po całym parku, podrywając panny.

„Spotkało mnie wielkie szczęście, na cześć losu śpiewam pieśń...” powtarzał raz za razem, nie pozwalając, by pasja handlarza osłabła. Na moje ucho, jego śpiew technicznie pozostawiał wiele do życzenia, ale głos, trzeba przyznać, miał całkiem niezły, w dodatku zdaje się, że nie do zdarcia, bo po kilku godzinach ćwiczeń nie słychać było w nim najmniejszego zmęczenia. Słońce także było niezmordowane, kurczyło i sklejało w jedną szarą masę cienie potężnych drzew, wysuszało na wiór nieroztropne dżdżownice, które spacerowały parkowymi dróżkami w najgorętszej porze dnia. Tuż przed południem spotykaliśmy się ponownie po wschodniej stronie ołtarza, spoglądał na mnie przelotnie, a ja na niego, on szedł na północ, ja na południe. Tak mijały miesiące, czułem, że w obu nas wzbiera ogromna chęć wzajemnego poznania, ale żaden nie wiedział, jak zacząć, więc tylko rzucaliśmy sobie za każdym razem przelotne spojrzenie, po czym opuszczaliśmy wzrok i szliśmy dalej, mijając się o włos. Im dłużej się to powtarzało, tym trudniej było zdobyć się na rozmowę. W końcu pewnego całkiem zwyczajnego dnia, bez żadnej szczególnej przyczyny, przywitaliśmy się na ścieżce skinieniem głowy. On powiedział: „Dzień dobry”, ja odpowiedziałem: „Dzień dobry”. On: „Wracasz”. Ja: „Tak, a ty?” On: „Na mnie też już czas". Obaj zwolniliśmy kroku (to znaczy ja wstrzymałem nieco wózek), mieliśmy ochotę jeszcze porozmawiać, ale nadal nie wiedzieliśmy, co powiedzieć. Minąwszy się, ponownie odwróciliśmy się do siebie.

On powiedział: „No to co, do zobaczenia...”. Ja odpowiedziałem: „No to do zobaczenia”. Uśmiechnęliśmy się do siebie i każdy ruszył w swoją stronę. Ale nie zobaczyliśmy się już, od tego czasu ani razu nie słyszałem w parku jego śpiewu, myślę sobie, że być może tamtego dnia chciał się ze mną pożegnać, może przyjęli go do jakiegoś zespołu albo grupy artystycznej? Mam szczerą nadzieję, że jak bohatera jego pieśni, tak i jego samego spotkało wielkie szczęście.

Pamiętam jeszcze parę innych osób, które często odwiedzały park. Był na przykład pewien starszy pan, prawdziwy weteran flaszki, u boku przymocowaną miał porcelanową piersióweczkę, wypełnioną oczywiście wódką. Popołudniowe spacery traktował jako sposób na zabicie czasu. Przechadzał się po całym parku, niezbyt wnikliwy 
obserwator mógłby pomyśleć, że kręci się tu nie jeden, a kilku takich staruszków, jednak poznawszy jego nietuzinkowe nawyki konsumpcyjne, absolutnie nie dało się go pomylić z nikim innym. Ubierał się niestarannie, chodził również niechlujnie, co pięćdziesiąt-sześćdziesiąt metrów przystawał, opierając jedną nogę na kamiennej ławeczce, kupce ziemi albo pniu ściętego drzewa, odczepiał od pasa buteleczkę, otwierając ją, mrużył oczy i uważnie badał wzrokiem wszystko, co znajdowało się $\mathrm{w}$ jego polu widzenia, następnie błyskawicznym gestem przysuwał sobie butelkę do ust i wlewał w siebie wielki łyk wódki, po czym potrząsał butelką i z powrotem zawieszał ją u pasa, zamyślał się na moment, zbierając siły na kolejne pięćdziesiąt-sześćdziesiąt metrów.

Pamiętam też pewnego gościa, który polował na ptaki. Ludzi było wtedy w parku niewielu, ale ptactwa za to w bród. W zagajniku w północno-zachodniej części rozciągnął siatkę, kiedy ptaki uderzały w nią, wplątywały się skrzydełkami i nie były w stanie się wydostać. Czekał na jakiś dawniej całkiem pospolity, ale dziś już rzadko spotykany gatunek, pozostałe ptaki, które dostawały się w sidła, wypuszczał na wolność. Mówił, że od wielu lat już tak czeka, że poczeka jeszcze rok, może jednak uda mu się złapać ten okaz. I tak powtarzał co roku przez kolejne wiele lat.

Rano i wieczorem widywałem w parku panią inżynier w wieku balzakowskim. Rano w drodze do pracy przechodziła przez park z północy na południe, wieczorem wracając do domu, szła od południa na północ. Właściwie to nie mam pojęcia, czym się zajmowała, ale byłem pewien, że musi być intelektualistką z technicznym wykształceniem, poznawałem to po rzadko spotykanej prostocie połączonej ze swoistą wytwornością. Kiedy przechodziła przez park, drzewa dokoła cichły, jakby wstrzymywały dech w piersiach, w bladym słonecznym świetle powietrze drżało jakby od dźwięków fortepianu, na którym ktoś wirtuozersko wygrywa na przykład „Dla Elizy”. Nie widziałem nigdy jej męża, nie wiem, jak wyglądał ten szczęśliwiec, również wyobraźnia nie podsuwała mi nigdy żadnej konkretnej wizji, później niespodziewanie nawiedziła mnie myśl, że najlepiej w ogóle go sobie nie wyobrażać, żeby w ogóle nie pojawiał się w tej historii. Kierując kroki do domu, kobieta wychodziła przez północną bramę.

Obawiałem się trochę, że w domu czeka ją praca w kuchni. Chociaż, $\mathrm{z}$ drugiej strony, takie kuchenne okoliczności mogłyby wyzwolić z niej zupełnie inny rodzaj piękna, nie takiego, które wyraża się w „Dla Elizy", ale w jakiejś innej kompozycji. No właśnie, w jakiej?

Była jeszcze jedna osoba, mój przyjaciel, najbardziej utalentowany i najbardziej niedoceniony biegacz długodystansowy. Podczas Rewolucji Kulturalnej siedział kilka lat w więzieniu za jakąś nieostrożną 
wypowiedź, po wyjściu na wolność trudno było mu znaleźć jakąkolwiek pracę. W końcu został tragarzem. Tak czy owak, nie mógł w życiu liczyć na równe traktowanie. Przygnębiony i zrezygnowany, ukojenia szukał $\mathrm{w}$ treningach. Kiedy wybierał się do parku pobiegać, zawsze z zegarkiem w ręku mierzyłem mu czas. Po każdym okrążeniu dawał mi znak, a ja zapisywałem wynik. Robił tak zwykle dwadzieścia kółek, czyli mniej więcej dwadzieścia kilometrów. Liczył na to, że może dzięki osiągnięciom sportowym uda mu się wywalczyć wreszcie prawdziwą wolność polityczną, miał nadzieję, że pomogą mu w tym obiektywy kamer i aparatów dziennikarzy oraz reportaże $w$ prasie. $W$ pierwszym roku podczas Biegu Wiosennego zajął piętnaste miejsce, zobaczył wtedy, że zdjęcia czołowej dziesiątki wiszą w gablocie prasowej na ulicy Chang'ańskiej, to go zmotywowało. Rok później był czwarty, ale w gablocie wywieszono tylko pierwszą trójkę. Nie poddawał się. Trzeciego roku, gdy przybiegł siódmy, w gablocie pojawiło się zdjęcie czołowej szóstki. Kiedy w czwartym roku zajął trzecie miejsce, w gablocie znalazła się tylko fotografia zwycięzcy. Za piątym razem w końcu wygrał i... omal mu serce nie pękło, gdy w gablocie zobaczył zdjęcie z widokiem na tłumy kibiców. Przez parę lat często we dwóch przesiadywaliśmy w parku do późnego wieczora, wylewając żale i klnąc na czym świat stoi, a potem wracaliśmy do domów, przy pożegnaniu upominając się wzajemnie: jeszcze nie pora umierać, pożyjemy, zobaczymy, może coś się jeszcze zmieni. Teraz kolega dawno zaprzestał treningów, posunął się w latach, nie dałby już rady biegać tak szybko. Kiedy po raz ostatni, w wieku trzydziestu ośmiu lat, startował w Biegu Wiosennym, znów zajął pierwsze miejsce, bijąc przy tym rekord zawodów. Jeden z trenerów powiedział wtedy do niego: „Szkoda, że nie odkryłem cię dziesięć lat temu". Z trudem zdobył się na uśmiech, nie komentując słów trenera, wieczorem przyszedł do parku i beznamiętnym tonem opowiedział mi o tym. Nie widziałem go już od lat, mieszka teraz daleko stąd z żoną i synem.

Nikt z tych ludzi nie przychodzi już do parku. Spośród jego starych bywalców pozostałem tylko ja i to starsze małżeństwo. Zresztą, z ich dwojga w pewnym momencie jedno również nagle przestało się pojawiać, przez jakiś czas mężczyzna samotnie spacerował o zmierzchu, krokiem znacznie mniej zdecydowanym, wolniejszym, martwiłem się wtedy potwornie, że jego żonie coś się stało. Na szczęście, gdy zima minęła, kobieta jak dawniej zjawiła się w parku, znów we dwójkę okrążali Świątynię, on wysoki, ona niska, wyglądali jak dwie wskazówki zegara poruszające się pod prąd czasu. Włosy kobiety mocno posiwiały, ale niezmiennie chodziła uczepiona ramienia mężczyzny, jak dziecko. „Uczepiona” nie jest chyba właściwym określeniem, może 
należałoby raczej powiedzieć „,wsparta”, przydałoby się słowo łączące te dwa znaczenia, chwilowo jednak nic nie przychodzi mi do głowy.

Mam też ciągle jeszcze w pamięci pewne dziecko - dziewczynkę, śliczną, ale jakże nieszczęśliwą... Spotkałem ją w tamto popołudnie przed piętnastu laty, kiedy po raz pierwszy zjawiłem się $\mathrm{w}$ parku. Miała wtedy ze trzy latka. Przycupnęła na ścieżce po zachodniej stronie Pawilonu Wstrzemięźliwości, żeby pozbierać „lampioniki”. Rośnie tam kilka roztrzeplinów, które latem rozkwitają gęstym, żółtym kwieciem, kiedy kwiaty opadną, na drzewach pozostają setki takich „lampioników", utworzonych przez trzy zrośnięte ze sobą listki stanowiące cieniutkie, delikatne ścianki. Lampioniki początkowo są zielone, potem stają się białe, a na koniec żółte, wówczas opadają na ziemię, pokrywając ją leciutkim dywanem. Misterna konstrukcja lampioników budzi zachwyt wśród spacerowiczów, dorośli także nie potrafią się oprzeć ich urokowi i podnoszą z ziemi jeden po drugim. Dziewczynka zbierała lampioniki, mamrocząc coś do siebie. Głos miała bardzo ładny, nie był to piskliwy głosik, jaki mają zwykle dzieci w jej wieku, wydawał się dojrzały, by nie rzec - gruby. Może to dlatego, że w tamto popołudnie w parku panowała rzadko spotykana cisza i spokój. Zdziwiło mnie, że takie malutkie dziecko samo biega po parku. Zapytałem ją, gdzie mieszka. Bezwiednie wskazała paluszkiem w którąś stronę, po czym zawołała brata. $\mathrm{Z}$ gęstych zarośli wzdłuż murów wyłonił się siedmio-, może ośmioletni chłopczyk, popatrzył na mnie, stwierdzając pewnie, że nie wyglądam na groźnego drania, uspokoił siostrzyczkę, zapewniając: „Jestem tutaj”. Po chwili znów zniknął pośród traw, by nałapać owadów. Udało mu się upolować modliszkę, konika polnego, cykadę i ważkę, swoimi trofeami zabawiał małą. Przez kolejne dwa czy trzy lata widziałem ich często, jak bawili się pod tymi gruszami, zawsze razem, nierozłączni, stopniowo dorastali. Potem długo, długo nie pojawiali się $\mathrm{w}$ parku. Pomyślałem, że pewnie muszą chodzić na lekcje, dziewczynka też była już w wieku szkolnym, wyrosła z dziecięcych zabaw, nie miała kiedy przychodzić tutaj. Nic szczególnego, nie ma powodu, by przejmować się takimi rzeczami. Gdyby nie to, że pewnego roku ponownie ujrzałem ich w parku, pewnie prędzej czy później zapomniałbym o nich.

Była niedziela, jeden $\mathrm{z}$ tych słonecznych a okrutnych poranków, w porze, kiedy cała ziemia usłana jest zwykle lampionikami. To wtedy po wielu latach odkryłem, że dziewczynka, którą kiedyś spotkałem, jest upośledzona. Siedziałem akurat w cieniu roztrzeplinu. Męczyłem 
się z zakończeniem jednej nowelki, zastanawiałem się, dlaczego niby miałaby się ona zakończyć tak a nie inaczej, a z drugiej strony sam nie wiedziałem, co właściwie mi $\mathrm{w}$ tym zakończeniu nie pasuje, udałem się więc do parku, licząc, że tam w spokoju będę mógł zdecydować, czy warto kontynuować tę nowelę, czy może lepiej zabrać się za coś nowego. Gdy tylko zatrzymałem wózek, zauważyłem, jak nieopodal grupka młodzieży zaczepia jakąś dziewczynę. Robili głupie miny, żeby ją przestraszyć, z krzykiem i śmiechem gonili ją, to znów zastawiali jej drogę, ona zaś biegała $\mathrm{w}$ popłochu między drzewami, cały czas zaciskając $\mathrm{w}$ dłoni uniesiony rąbek spódnicy, chyba nawet nie zdawała sobie sprawy, że pogubiła buty i biega boso.

Zorientowałem się, że dziewczynka nie jest do końca sprawna umysłowo, ale w pierwszej chwili nie rozpoznałem jej. Już miałem podjechać i osłonić ją, gdy zobaczyłem, że z daleka na rowerze pędzi chłopak. Na jego widok grupka się rozproszyła. Chłopak zahamował i zatrzymał się tuż obok, rzucił gniewne spojrzenie uciekającym gdzie pieprz rośnie chuliganom. Stał bez słowa, ciężko oddychając. Jego twarz robiła się coraz bledsza i bledsza, jak niebo przed nawałnicą. Wtedy ich poznałem, tak, to było to samo rodzeństwo, które widywałem dawniej. O mało nie wydarł mi się wzbierający w duszy okrzyk zdziwienia albo może raczej litości. Są na tym świecie rzeczy, które sprawiają, że człowiek zaczyna wątpić w czystość Boskich intencji. Chłopiec podszedł do siostry. Dziewczyna rozluźniła uchwyt, opuszczając rąbek spódnicy, na ziemię wysypały się uzbierane przez nią lampioniki, zasypując jej nagie stopy. Nadal była ładna, tylko że jej oczy były jakby nieobecne, brak w nich było błysku. Patrzyła bez emocji, jak ci, którzy przed chwilą jej dokuczali, rozbiegają się na wszystkie strony, a potem długo jeszcze stała ze wzrokiem utkwionym w pustkę. Czy jej umysł jest w stanie pojąć cokolwiek z zawiłości tego świata? Pod drzewem przecedzone przez korony drzew światło słoneczne kładło się na ziemi, tworząc jasne plamki, jakby gwiazdy na nocnym niebie. Lampioniki wirowały na wietrze jak małe dzwoneczki bez serc. Brat pomógł dziewczynce wsiąść na bagażnik i razem pomknęli rowerem do domu.

Milczenie jest najwłaściwszym komentarzem. Piękno i ułomność. Skoro Bóg postanowił obdarzyć ją tymi dwoma rzeczami, to nie pozostaje nic innego jak milczeć i wrócić do domu.

Zresztą, czy ktokolwiek z ludzi jest w stanie zrozumieć ten świat? Są sprawy, o których nie wolno mówić. Można mieć pretensje do Boga, że niepotrzebnie zsyła na ludzi tyle cierpień, można próbować walczyć z tymi cierpieniami i szczycić się tym, odczuwać dumę po każdym drobnym sukcesie, ale wystarczy, że dłużej się nad tym zastanowić, by zwątpić w słuszność swoich roszczeń. Czy gdyby nie było cierpienia, 
świat mógłby w ogóle istnieć? Gdyby nie było głupoty, cóż niezwykłego byłoby w bystrości umysłu? Gdyby nie brzydota, czy pięknu nadal wiodłoby się tak dobrze? Gdyby nie zło i podłość, jak mogłyby ukształtować się dobro i szlachetność, i na jakiej podstawie urosnąć miałyby do rangi cnót? Czy gdyby nie słabość i ułomność, zdrowie nie spowszedniałoby ludziom, nie znudziłoby się im? Często marzę o tym, żeby ze świata zniknęło wszelkie kalectwo, gdyby jednak usunąć kalectwo, aby suma cierpienia na ziemi pozostała niezmienna, prawdopodobnie wszystkie problemy kalekich spadłyby wówczas na chorych. Jeśliby wyeliminować również wszystkie choroby, to ta porcja cierpienia przypadłaby w udziale (na przykład) brzydkim. A jeślibyśmy pozbyli się także brzydoty, głupoty, podłości i wszystkich tych cech i zachowań, które nam się nie podobają, i dzięki temu wszyscy stali się tak samo zdrowi, piękni, mądrzy, szlachetni, co by to było? Obawiam się, że wyczerpawszy repertuar, upadłby teatr świata tego. Świat pozbawiony różnic byłby jak Morze Martwe, stałby się obojętny i jałowy jak pustynny piach.

Wygląda na to, że różnice zawsze będą niezbędne. Wygląda na to, że nie mamy innego wyjścia jak tylko zaakceptować cierpienie - cały ten ludzki teatr nie mógłby istnieć bez niego, ba, samo istnienie w ogóle nie byłoby możliwe. Wydaje się, że Bóg i w tym miał rację.

Wnioski, jakie $\mathrm{z}$ tego płyną, nie pozostawiają nam najmniejszych złudzeń. Bo jak w takim razie rozstrzygnąć, komu powinny przypaść w udziale role naznaczone cierpieniem, a kto miałby uosabiać szczęście, chwałę i radość tego świata? Kwestia przypadku, ot, cała filozofia.

Los nie poddaje się wyrokom sprawiedliwości.

Gdzie w takim razie szukać mają ukojenia ci, dla których fortuna nie okazała się łaskawa?

Gdyby wybawić człowieka mogły mądrość i zrozumienie, to czy aby na pewno wszyscy potrafiliby zdobyć się na nie i w nich znaleźć duchowy azyl?

Często myślę sobie, że to brzydkim kopciuszkom zawdzięczają swoje istnienie piękne damy. Że to głupcy wskazują mędrców. Że śmiertelnicy stwarzają bogów.

Jeśli istnieje jakiś Duch Parku, który przenika to miejsce i zna na wylot wszystkich jego bywalców, wie na pewno, że od tylu lat przychodzę tu $\mathrm{w}$ najróżniejszych nastrojach, czasem radosny, innym razem przygnębiony, czasem beztroski, kiedy indziej przytłoczony samotnością, czasem spokojny, pewny siebie, a potem znów pełen obaw, zagubiony, 
tak naprawdę jednak przez te wszystkie lata dręczą mnie tylko trzy pytania. Po pierwsze: umierać albo nie umierać? Po drugie: po co żyć? Po trzecie: czemu właściwie piszę?

Pozwólcie, że prześledzę teraz historię moich zmagań z tymi trzema problemami od początku aż do dziś.

Mówiłeś, że śmierci przynaglać nie trzeba, bo tak czy tak przyjdzie, nie da się jej przegapić, choćby się całe życie przespało, na śmierć się nie zaśpi, co więc szkodzi popróbować jednak trochę pożyć, nim niechybnie przyjdzie? Racja, przynajmniej w najogólniejszych założeniach. Dlaczego postanowiłeś jednak spróbować żyć? Głównie dlatego chyba, że nie chciałem się tak łatwo poddawać, to w końcu rzadka okazja, jedyna w swoim rodzaju, szkoda byłoby nie skorzystać, kto się raz wycofa z tej gry, już do niej nie wróci, a taka próba nic nas przecież nie kosztuje, niczym nie ryzykujemy, niczego nie tracimy, bóg śmierci nigdy nie zawodzi, śmierć nasza nie jest zagrożona. No właśnie, a nuż uda się jeszcze coś zyskać, prawda? Jak mówiłem, ta myśl bardzo mnie uspokoiła, sprawiła, że poczułem się dużo swobodniej. Czemu w takim razie piszesz? Powszechnie wiadomo, że „pisarz”, samo to słowo, brzmi dumnie i budzi respekt. Nie ma przecież nic złego w tym, że przesiadujący w parku kaleka ma nadzieję pewnego dnia zyskać trochę szacunku i podziwu w oczach ludzi, wyrobić sobie jakąś przyzwoitą pozycję, choćby nawet zaraz po tym miał umrzeć. Na początku tak właśnie myślałem, nie trzeba $\mathrm{z}$ tego robić tajemnicy, teraz nie muszę już tego ukrywać.

Zabierałem do parku zeszyt i długopis, zaszywałem się w miejscu najmniej uczęszczanym przez ludzi i pisałem w ukryciu. Znajomy śpiewak śpiewał bez wytchnienia w pobliżu. Kiedy ktoś się zbliżał, zamykałem zeszyt, a długopis wsadzałem do ust. Bałem się, że jeśli nic $\mathrm{z}$ tego pisania nie wyjdzie, to będzie wstyd. Bardzo przejmowałem się swoim wizerunkiem. No ale przecież udało ci się to skończyć, i na dodatek opublikować. Ludzie mówią, że piszę całkiem nieźle, niektórzy dodają nawet: nigdy byśmy nie przypuszczali, że tak świetnie piszesz. Cóż mogę wam odpowiedzieć, wiele jest jeszcze na tym świecie rzeczy, o których wam się nie śniło. W rzeczywistości jednak, gdy słyszę te słowa, rozpiera mnie radość. Chciałbym, aby i ten znajomy śpiewak mógł usłyszeć podobną pochwałę, bo przecież naprawdę śpiewa całkiem nieźle. Kiedy zwróciłem się w ten sposób do mojego przyjaciela biegacza, akurat przechodziła obok nas elegancka pani inżynier. Był bardzo poruszony moimi słowami, powiedział, skoro tak, to od dzisiaj wszystko postawię na bieganie. A ty postawisz wszystko na pisanie. I w tym momencie wstąpił w ciebie jakby demon, całymi dniami myślałeś tylko o tym, które ze zdarzeń mógłbyś opisać, który człowiek 
nadaje się na bohatera twojej powieści. Tak, dosłownie jak nawiedzony, chodziłem tu i tam, z morza ludzi usiłowałem wyłowić powieść. Och, gdyby istniała jakaś wyciskarka do powieści, za pomocą której można by z każdego człowieka wycisnąć dwie kropelki esencji i sprawdzić, czy w jego żyłach płynie powieściowa krew, gdyby istniał jakiś wykrywacz powieściowości $\mathrm{w}$ postaci cieczy, którą można by rozlać po całym świecie i która zmieniałaby kolor, reagując z substancją literacką... Kompletnie nawiedzony. Żyłem wtedy tylko po to, by pisać. W rezultacie opublikowałeś znów parę tekstów, usłyszał o tobie kawałek świata, i wtedy właśnie zaczął wzbierać w tobie coraz większy strach. Nagle wydało mi się, że oto żyję jak jeniec, przed chwilą miałem okazję pożyć trochę jak człowiek, ale przebrałem miarkę i teraz jestem jak zakładnik, złapany przez jakieś służby specjalne, czekający w niepewności na wyrok, nie wiedząc, którego dnia zostanę stracony. Obawiałeś się, że jeszcze trochę, a skończy się twoja dobra passa, że koniec z natchnieniem, i wtedy - już po tobie. Bo jak to możliwe, żebym bez przerwy, w nieskończoność pisał? Z jakiej racji miałyby te wszystkie nadające się na powieść fragmenty rzeczywistości bezustannie przybywać i kłaść się u bezwładnych stóp jakiegoś kaleki? Inni pisarze przemierzają cały świat i też nie omijają ich twórcze kryzysy, więc jakim cudem ja, siedząc wiecznie w tym jednym parku, miałbym produkować powieść za powieścią? A ty znowu o śmierci. Myślę sobie, że trzeba wiedzieć, kiedy wypada zejść ze sceny, należy zachować umiar. Bycie jeńcem jest zbyt męczące, ciągle trwa się w napięciu, budząc się, nie wiesz, czy dożyjesz wieczoru. Żyję dalej tylko po to, żeby pisać, ale jeśli pisanie wcale nie jest tym, co powinienem robić, to czy dalsze życie nie jest po prostu głupotą? Tak myślałeś, a jednak cały czas siódme poty wylewałeś nad kartką. Na szczęście jeszcze tym razem udało mi się z suchego ręcznika wycisnąć parę kropelek wody. Doba przeżyta w strachu trwa więcej niż dwadzieścia cztery godziny, poczucie, że w każdej chwili może nastąpić koniec, jest gorsze niż sam koniec, strach ma wielkie oczy, to już lepiej jest umrzeć, lepiej się nie rodzić, lepiej, żeby w ogóle nie było tego świata. Mimo to nie zdecydowałeś się umrzeć. Znów pomyślałem, że z tym nie należy się spieszyć. Ale to, że z czymś nie należy się spieszyć, nie znaczy jeszcze, że należy to opóźniać, prawda? Skoro ostatecznie postanowiłeś żyć, o czym to świadczy? Racja, jednak chcę żyć.

Dlaczego człowiek żyje? Bo chce żyć. Ostatecznie o to właśnie chodzi, prawdziwe imię człowieka to Pragnienie. Ale ja się nie boję śmierci, czasami naprawdę nie boję się umrzeć. Czasami - dobrze powiedziane, czasami. Nie bać się śmierci i chcieć śmierci to dwie różne sprawy. Ludzie, którzy czasami nie boją się śmierci, zdarzają się, 
owszem, ale jeszcze się nie urodził taki, który ani przez chwilę by się jej nie bał. Czasami boję się żyć. Ale czy bać się żyć oznacza to samo, co nie chcieć żyć? Ale dlaczego ja jeszcze chcę żyć? Bo chciałbyś jeszcze coś dostać, bo na coś jeszcze liczysz, na przykład na miłość albo może jakąś inną wartość, prawdziwe imię człowieka to Pragnienie, nie mam racji? Nie powinienem na nic liczyć? A kto mówi, że nie powinieneś? Tylko dlaczego ciągle żyję w strachu, jak jeniec? Potem zrozumiałeś, zrozumiałeś, że się myliłeś. Nie żyje się, żeby pisać, lecz pisze się, żeby żyć. Zrozumiałeś to w dość komicznych okolicznościach.

Tamtego dnia, gdy po raz kolejny powtórzyłeś, że lepiej by było, gdybyś umarł, jeden z przyjaciół pocieszył cię: Nie możesz umrzeć, musisz pisać dalej, masz jeszcze do napisania tyle dobrych książek. Wtedy nagle cię olśniło, powiedziałeś: Muszę pisać tylko dlatego, że żyję. Albo raczej - musisz pisać tylko dlatego, że chcesz żyć. Prawda, te słowa sprawiły, że przestałem się aż tak bać. To był ten rodzaj ulgi, jaką odczuwa się, kiedy przejrzy się na wylot zamysły śmierci? Najlepszy sposób, jakim dysponuje jeniec, by zemścić się na tych, którzy go pojmali, to samobójstwo. Rozumiem, że powinienem się zabić na jakimś rynku, wtedy nie musiałbym już uczestniczyć w całym tym marketingowym jazgocie, $w$ tym absurdalnym handlu tematami. Nadal piszesz? Nadal piszę. Naprawdę musisz pisać? Człowiek nie potrafi żyć, jeśli nie znajdzie sobie jakiegoś sensownego powodu uzasadniającego własne istnienie. Nie boisz się wypalenia? Nie wiem, ale myślę, że problemu życia nie sposób rozwiązać przed śmiercią. Tak lepiej. Już się nie boisz, więc nie jesteś już zakładnikiem, jesteś wolny. Daj spokój, jak można mówić, że ja jestem wolny? Nie zapominaj, że prawdziwe imię człowieka to Pragnienie. No tak, ale wiem też, że najefektywniejszym sposobem, by unicestwić człowieczeństwo, jest unicestwić pragnienia. W takim razie może by tak unicestwić pragnienia i tym samym na zawsze uwolnić się od strachu? A może jednak zachować pragnienia, a wraz z nimi życie?

Kiedy tak siedziałem w parku, Duch Parku powiedział mi: Każdy grający z pasją aktor prędzej czy później staje się zakładnikiem. Każdy widz rozumiejący widowisko genialnie niweczy misterny spisek konspiratora. Kiepscy aktorzy to ci, którzy uparcie twierdzą, że to, co grają, nie ma związku z nimi samymi.

Niewydarzony widz to taki, który zawsze siada zbyt blisko sceny.

Siedziałem w parku, a Duch Parku niestrudzenie powtarzał mi: Synu, zrozum, to jest twoje błogosławieństwo i przekleństwo. 
VII

Jeśli o czymś nie napisałem, Świątynio Ziemi, to nie dlatego, że zapomniałem, niczego nie zapomniałem, ale są rzeczy, które trzeba przechowywać w ukryciu. Nie wolno o nich mówić, nie wolno myśleć, ale nie wolno też zapomnieć. Wymykają się słowom, kontakt z językiem sprawia, że przestają być tym, czym były. To mglista czułość i samotność, najdłużej chowana nadzieja i rozczarowanie. Pomieszczą je tylko dwa miejsca: serce i grób. To tak jak ze znaczkami, jedne nakleja się na listy, a inne wkłada się do klasera.

Dziś, gdy tak spaceruję po ogrodzie, często nawiedza mnie dziwne odczucie, przychodzi mi do głowy, że za długo już tak w pojedynkę zabawiam się tutaj. Pewnego dnia, porządkując stare albumy, natknąłem się na takie zdjęcie: młody chłopak siedzi na wózku, za jego plecami rośnie wiekowy cyprys, w oddali widać główny ołtarz Świątyni. Postanowiłem odszukać to drzewo. Konfrontując tło zdjęcia z widokami w parku, odnalazłem je bardzo szybko, porównałem także układ gałęzi, to na pewno był ten sam cyprys. Okazało się jednak, że jest już martwy, a jego pień oplatają bujne pędy wistarii.

Któregoś razu w parku zagadnęła mnie pewna staruszka: „O, a ty nadal tutaj?"

I dodała: „A co u twojej matki?”

„Kim pani jest?”

„Nie pamiętasz mnie, ale ja ciebie pamiętam. Pamiętam, jak kiedyś twoja matka szukała cię tu, spytała mnie wtedy, czy nie widziałam gdzieś chłopca na wózku".

Pomyślałem nagle, że naprawdę zbyt długo zabawiam się sam na tym świecie. Innym razem, nocą, siedziałem sobie niedaleko ołtarza, w świetle latarni czytając książkę. Nagle z ciemności otaczających ołtarz dobiegł moich uszu dźwięk rogu. Przede mną znajdowała się licząca kilkaset metrów kwadratowych pusta platforma, pośrodku której stał ołtarz, samotny pośrednik między Niebiosami a Ziemią. Platformę otaczały potężne stare drzewa. Nigdzie nie było widać grającego na rogu człowieka. Dźwięk rogu w tę niemal bezgwiezdną noc to przycichał, to znów niósł się głośnym echem, brzmiał na przemian żałośnie i wesoło, to łagodny, to zimny i obojętny. Nie potrafię w kilku słowach oddać jego brzmienia. Słyszałem w nim wyraźnie przeszłość, teraźniejszość i przyszłość, zaklęte w wiecznej melodii.

Nadejdzie taki dzień, gdy wezwie mnie do powrotu.

A wtedy... Wyobraźcie sobie dziecko, które mimo zmęczenia chciałoby się bawić dalej. W jego głowie rodzą się ciągle nowe pomysły, już nie może się doczekać jutra. Albo wyobraźcie sobie starca, który udaje 
się na zasłużoną emeryturę, ustąpiwszy ze stanowiska, wraca do domu, stąpa twardo, pewnie, z poczuciem dobrze wypełnionej misji, nie zważając na dające się słyszeć tu i ówdzie pomruki niezadowolenia. Albo jeszcze wyobraźcie sobie parę kochających się ludzi, którzy powtarzają sobie bez przerwy: „Nie chcę się z tobą rozstawać ani na chwilę”, a potem zaraz: „Już późno”, „już późno, ale nie chcę się $\mathrm{z}$ tobą rozstawać ani na chwilę, ani na kwadrans nie chcę się z tobą rozstawać, ale jest już tak późno".

Nie potrafię powiedzieć, czy chciałbym wracać, czy nie. Nie potrafię powiedzieć, czy chciałbym, czy nie chciał, czy może jest mi wszystko jedno. Nie potrafię powiedzieć, czy byłbym jak to dziecko, czy jak ten starzec, a może jak ci zakochani. Niewykluczone, że byłbym nimi wszystkimi jednocześnie. Na początku, jak każdy, byłem dzieckiem, które płacząc i krzycząc, wyrywa się najpierw z łona, a potem $\mathrm{z}$ objęć matki. Kiedy tylko zaczyna poznawać ten świat, staje się jak szalony kochanek, który niezależnie ile miałby czasu, zawsze będzie przekonany, że życie upływa za szybko, który zaczyna boleśnie rozumieć, że droga, którą kroczy, to w istocie droga powrotna. Że kiedy witają go fanfary, w tle brzmi już pogrzebowa trąbka.

A jednak słońce w każdej chwili wschodzi i zachodzi jednocześnie. Gdy gaśnie i znika za górami, pozostawiając po sobie ciemność i chłód, gdzieś tam, po drugiej stronie wznosi się ponad szczyty, niosąc światło i ciepło. Kiedy nadejdzie pora, ja również, podpierając się laseczką, pokuśtykam cichutko za góry.

Pewnego dnia w górskiej dolinie zjawi się dziecko, będzie biegać radośnie, przyciskając do piersi maskotkę.

Oczywiście, to nie będę ja.

Ale... czy to nie będę ja?

Wszechświat swym nieustającym Pragnieniem przeistacza ulotny taniec $\mathrm{w}$ wieczne widowisko. Jakie ziemskie imię nadamy temu Pragnieniu, jest kwestią najzupełniej drugorzędną.

Rok 1989

ttum. Joanna Krenz 